\title{
Prognostic value of HER2 status in bladder transitional cell carcinoma revealed by both $\mathrm{IHC}$ and BDISH techniques
}

Taoufik Nedjadi ${ }^{1}$, Jaudah Al-Maghrabi ${ }^{2}$, Mourad Assidi $^{3}$, Ashraf Dallol ${ }^{3}$, Heba Al-Kattabi ${ }^{3}$, Adeel Chaudhary ${ }^{3}$, Ahmed Al-Sayyad ${ }^{4}$, Adel Al-Ammari ${ }^{5}$, Adel Abuzenadah ${ }^{3}$, Abdelbaset Buhmeida ${ }^{3^{*}}$ and Mohammed Al-Qahtani ${ }^{3}$

\begin{abstract}
Background: Her2/neu is an oncogene that plays an important role in the pathogenesis of many cancer types. In bladder carcinoma (BC), the clinical significance of Her2/neu status remains under-investigated and poorly linked to the patients' clinic-pathological features and survival status. Thus, the current study was conducted to assess Her2/ neu status in a cohort of patients' in Saudi Arabia, and to explore its prognostic value in BC.
\end{abstract}

Methods: A total of 160 consent patients of transitional cell carcinoma (TCC) of bladder were arranged on a tissue microarray (TMA) and stained by immunohistochemistry (IHC) and bright-field dual in situ hybridization (BDISH) methods. The intensity of Her2/neu protein receptor immunostaining was evaluated, correlated to Her2/neu gene amplification status in TCC and assessed for potential clinical value by correlation measures.

Results: IHC data demonstrated that Her2/neu protein is expressed in $60 \%$ (2+ and 3+) of our TCC patient's cohort from Saudi Arabia. Her2/neu gene amplification is detected in $25 \%$ by BDISH. There was a strong association between Her2/neu protein levels and lymph node invasion $(p=0.04)$, tumor stage $(p=0.002)$, vascular invasion and borderline significance with distant metastasis $(p=0.07)$. Amplification of Her $2 /$ neu gene was associated with tumor grade $(p=0.03)$ and poor disease-specific survival $(p=0.02)$, in that, patients with non-amplified Her2/neu gene live longer. Interestingly, there was a reasonable concordance rate $(71 \%)$ between $\mathrm{HC}$ and $\mathrm{BDISH}$ data in the analyzed cohort.

Conclusion: The study showed that $25 \%$ of our patients' cohort has Her2/neu over-expression. This Her2/neu (over-expression/amplification) status was concordant using either IHC or BDISH and significantly associated with disease aggressiveness and poor outcome. These findings suggested a potential impact of anti-Her2 targeted therapy in the treatment of bladder cancer with amplified/overexpressed HER2 that needs further investigation.

Keywords: Her2/neu, IHC, BDISH, Prognosis, Transitional cell carcinoma of bladder

Abbreviations: ASCO, American society of clinical oncology; BC, Bladder cancer; BDISH, Bright field double in situ hybridization; CAP, College of American pathologists; DFS, Disease free survival; DSS, Disease specific survival; FDS, Food and drug authority; Her2, Human epidermal growth factor receptor 2; IHC, Immunohistochemistry; TCC, Transitional cell carcinoma; TMA, Tissue microarray; TNM, Tumor, node and metastasis

\footnotetext{
* Correspondence: abuhme@utu.fi

${ }^{3}$ Center of Excellence in Genomic Medicine Research, Faculty of Applied

Medical Sciences, King Abdulaziz University, PO BOX 80216, Jeddah 21589,

Saudi Arabia

Full list of author information is available at the end of the article
} 


\section{Background}

Bladder cancer (BC) is a devastating disease and a leading cause of death worldwide [1]. According to a recently published data, $\mathrm{BC}$ is the sixth most common malignancy with an estimated 74,000 new cases and more than 15,000 deaths of bladder cancer in the United States on 2015 [2]. Despite important advances in cancer treatment, the disease continues to pose a big challenge to clinicians due to high recurrence rates, as $50-70 \%$ of new cancer cases recur within 5 years, and a great likelihood to progress to an aggressive, muscle invasive and metastatic forms $[3,4]$.

The management of $\mathrm{BC}$ relies enormously on the patients' clinico-pathological parameters, such as TNM staging andgrading of the tumor, as indicators of good/poor prognosis. However, these parameters are not sufficient to predict patients' outcome and worse yet, produce large discrepancies within the same grade/stage. This is mainly related to heterogeneity of bladder cancer cells [5]. Intensive efforts are being made to develop novel molecular tools in order to assist in the detection of the disease at an early stage, enhance stratification of high risk patients and improve clinical management $[6,7]$. Although initially promising, most of these tools have not been sufficiently sensitive or specific which necessitate the identification of additional robust biomarkers that would more accurately predict for patient's prognosis and improve therefore $\mathrm{BC}$ surveillance in clinical setting.

The human epidermal growth factor receptor-2 (Her2/ neu) is a transmembrane glycoprotein, member of the EGF family of tyrosine kinase receptors encoded by the Her2/neu proto-oncogene [8]. In normal circumstances, cells have low Her2 membrane protein content involved in proliferation, differentiation, angiogenesis, and invasion [9] but it increases dramatically in cancer cells. It has been reported that Her2/neu protein is overexpressed in several malignancies especially in gastric (20\%) and breast cancers (up to $30 \%$ ) [10-12]. It is well documented that Her2/neu over-expression is associated with poor prognostic in breast cancer. Also, data emerging from clinical trials revealed that the addition of the monoclonal antibody against Her2/neu protein (trastuzumab) to chemotherapy enhanced the overall patients' survival $[13,14]$.

A recent analysis of Her2/neu expression status in a large cohort of patients across divers malignancies revealed that bladder cancer exhibited a significant Her2/ neu protein over-expression (3+) assessed by immunohistochemistry (IHC) in more than $12 \%$ of patients [15]. In an independent study using 111 BC samples, Bellmunt et al. demonstrated that Her2/neu over-expression was observed in $22 \%$ of the analyzed cohort [16], and could reached in some cases a record ratio of $74 \%$, as reported elsewhere [17]. This is an interesting finding that indicates that a large proportion of $\mathrm{BC}$ patients could benefit from targeted anti- Her2/neu therapies. Moreover, a number of phase II/III clinical trials are currently underway to assess the beneficial effect of antiHer2/neu and other therapies in urological cancer [18]. The aim of the present study is to determine the status of Her2/neu in bladder cancer using two independent methods IHC and BDISH. The level of concordance between the two methods will be evaluated. Correlation between Her2/neu over-expression or gene amplification with patients' clinico-pathological parameters and the significance of $\mathrm{Her} 2 / \mathrm{neu}$ as a prognostic biomarker in bladder cancer will be investigated.

\section{Methods}

Patients

The present series consists of 160 formalin-fixed and paraffin-embedded (FFPE) tissue samples of primary transitional cell carcinoma of bladder cancer retrieved from consent patients' materials in the archives of the Pathology Department, King Abdulaziz University Hospital (KAUH) (Ethical Approval of KAUH IRB \# 149-14). Patients were diagnosed and treated mainly at the Departments of Pathology \& Urology, King Abdulaziz University Hospital (KAUH) and King Faisal Specialist Hospital and Research Center (KFSHR), between 1996 and 2012. Only specimens containing more than $80 \%$ tumor cells were used for analysis. The histo-pathological features of the carcinoma specimens were classified according to the TNM classification system. All clinical and pathological data of the patients were collected from the patients' medical records. The key clinico-pathological data of the patients are shown in Table 1.

\section{Tissue microarray}

Based on tissue microarray technique (TMA) as previously described [19], we successfully transferred approximately 160 blocks of bladder cancer to construct TMA slides for evaluating the expression pattern of Her2/neu status. Moreover, we also validated the TMA technique in an integrative and comprehensive approach with IHC for protein profiling of Her2/neu protein and BDISH for Her2/neu gene profiling in bladder cancer samples. The TMA technique seems to us as a feasible, useful and multipurpose platform.

\section{Immunohistochemistry (IHC)}

Overexpression of Her2/neu protein was detected automatically by IHC. The FDA-approved Her2/neu IHC assay using PATHWAY Her2/neu rabbit monoclonal antibody (clone 4B5; Ventana) was performed with iView DAB Detection Kit (Ventana) on a BenchMark $\mathrm{XT}$ automated staining system (Ventana). A protocol was established so that the entire assay procedure 
Table 1 Clinico-pathological characteristics of 160 patients of transitional cell carcinoma of urinary bladder

\begin{tabular}{ll}
\hline Clinico-pathological features & Patients number (\%) \\
\hline Gender & $133(83 \%)$ \\
Male & $27(17 \%)$ \\
Female & \\
Age group (years) & $70(44 \%)$ \\
$\quad \leq 60$ & $89(56 \%)$ \\
$>60$ & \\
Lymph node involvement & $18(17 \%)$ \\
Yes & $86(83 \%)$ \\
No & \\
Distant metastasis & $17(17 \%)$ \\
Yes & $83(83 \%)$ \\
No & \\
Tumor Stage & $100(76 \%)$ \\
I/II & $32(24 \%)$ \\
III/IV & \\
Tumor grade & \\
Low grade & $68(44 \%)$ \\
High grade & $85(56 \%)$ \\
Vascular invasion & \\
Yes & $107(68 \%)$ \\
No & \\
Recurrence & \\
Yes & \\
\hline
\end{tabular}

consisting of deparaffinization with EZ Prep (Ventana) at $75{ }^{\circ} \mathrm{C}$, heat pretreatment in Cell Conditioning 1 (CC1; Ventana) using "conditioner CC1 8 min,Mild CC1 $30 \mathrm{~min}$ " for antigen retrieval at $100{ }^{\circ} \mathrm{C}$, and then incubation with the anti- Her2/neu primary antibody for $16 \mathrm{~min}$ at $37{ }^{\circ} \mathrm{C}$. The slides were counterstained with Hematoxylin II (Ventana) for $4 \mathrm{~min}$ and Bluing Reagent (Ventana) for $4 \mathrm{~min}$. At the completion of the run, the slides were removed from the automated slide stainer. Following the staining step, the slides having residual buffer and liquid coverslip solution on them were rinsed first with a mild detergent followed by water until complete removal of the soap. The slides were then immersed into successive alcohol buffer at different concentrations $(70 \%, 95 \%, 100 \%)$ for 3 min to each. Then one drop of Tissue-Tek glas mounting medium was applied onto a slide and covered with the glass coverslip.
Bright Field Double In Situ Hybridization (BDISH)

Her2/neu and Chromosome 17 probes were detected using two colors chromogenic in situ hybridization (ISH) in formalin-fixed, paraffin-embedded human bladder cancer tissue specimens following staining on VENTANA BenchMark XT automated slide stainer, by light microscopy. The INFORM Her2/neu Dual ISH DNA Probe Cocktail contains a Her2/neu probe (labeled with the hapten dinitrophenyl or DNP) and a Chromosome 17 centromere probe (labeled with the hapten digoxigenin or DIG) formulated with human placental blocking DNA in a formamide-based buffer. The probes were designed to detect amplification of the Her2/neu gene in solid tumors. A protocol was established so that the entire assay procedure consisting of baking for $30 \mathrm{~min}$, deparaffinization with EZ Prep (Ventana) at $75^{\circ} \mathrm{C}$, cell conditioning 2 (CC2; Ventana) using "Mild CC2 cycle $8 \mathrm{~min}$, standard CC2 cycle $12 \mathrm{~min}$, extended cycle $8 \mathrm{~min}$ " followed by protease digestion with ISH protease 3 (ventana) for $16 \mathrm{~min}$ at $37^{\circ} \mathrm{C}$. The genomic DNA in tissue sections and the nick-translated HER2 and CEN17 probes were denatured by heat treatment for $20 \mathrm{~min}$ at $80{ }^{\circ} \mathrm{C}$ followed by a hybridization step for $6 \mathrm{~h}$ at $44{ }^{\circ} \mathrm{C}$. After that, 3 stringency wash steps were performed at $72{ }^{\circ} \mathrm{C}$ with $2 \times$ SCC (Ventana). For HER2 gene detection, the slides were incubated with a rabbit anti-DNP antibody for $20 \mathrm{~min}$ and then with HRP-conjugated anti-rabbit antibody for $16 \mathrm{~min}$ at $37^{\circ} \mathrm{C}$. The Her2/neu BDISH signal was detected as metallic silver deposits with silver acetate, hydroquinone, and hydrogen peroxide for $4 \mathrm{~min}$ at $37^{\circ} \mathrm{C}$. For CEN17 detection, the slides were incubated with a mouse anti-DIG antibody for $20 \mathrm{~min}$ and then with an alkaline phosphatase (AP)-conjugated anti-mouse antibody for $24 \mathrm{~min}$ at $37{ }^{\circ} \mathrm{C}$. The CEN17 $\mathrm{BISH}$ signal was developed as red dot staining with fast red and naphthol phosphate for $8 \mathrm{~min}$. Finally, the slides were counterstained with Hematoxylin II for $8 \mathrm{~min}$ and with Bluing Reagent for $4 \mathrm{~min}$. At the completion of the run, stained slides having residual buffer and liquid coverslip solution were rinsed in a mild detergent to remove the coverslip solution, then rinsed with water only until soap was completely removed and finally dried at $45{ }^{\circ} \mathrm{C}$ for $15 \mathrm{~min}$. Slides were thereafter transferred into xylene bath for approximately $30 \mathrm{~s}$ then coverslips were applied by the Tissue-Tek Film Cover slipper.

\section{Scoring system of Her2 gene/protein amplification/ expression status}

In order to assess both Her2/neu protein expression pattern and corresponding gene amplification status in bladder cancer, we have used the same scoring system that has already been implemented for breast cancer following the current ASCO/CAP guidelines [20]. The scoring method for Her2 protein expression is based on 
the cell membrane staining pattern. Her2/neu testing results by IHC fall into 3 categories: positive, equivocal, and negative. Each of these results triggers different patient management. Cancer samples with equivocal IHC were validated using BDISH to assess the HER2 gene amplification status. The interpretation for Her2/neu BDISH testing (Her2/neu/Chr17 ratio) is according to (ASCO/CAP) scoring systems. BDISH staining results in visualization via light microscopy in which Her2/neu appears as discrete black signals (SISH) and $\mathrm{Chr} 17$ as red signals (Red ISH) in nuclei of cells. The Scoring Algorithm for the Her2/neu Dual ISH DNA Probe Cocktail is as following; non-amplified (Her2/neu/CEP17 ratio <1.8), equivocal (HER2/CEP17 ratio $1.8-2.2$ ), and amplified (Her2/neu /CEP17 ratio >2.2). However, according to new regulation of ASCO/CAP guidelines for ISH technique if the result is equivocal (Her $2 / n e u /$ CEP17 ratio is $1.8-2.2$ ), you have to count extra 20 cells for both Her2/neu and CEP17 and calculate the ratio once again. If the ratio is below $<2$, non-amplified; and if ratio is above $>2$, it is amplified.

\section{Control samples}

For quality control purposes, we used Her2/neu Dual ISH 3-in-1 Xenograft of breast cancer slides provided by the company (Roche Diagnostics GmbH, Mannheim, Germany) representing the Her2/neu gene status in its 3 different categories; amplified $(+3)$, equivocal $(+2)$ and non-amplified $(0,+1)$, respectively. We stained these xenograft tumor slides throughout the same run for staining bladder cancer samples in both IHC and BDISH experiments.

\section{Statistical analysis}

Statistical analyses were performed using the SPSS $^{\circ}$ (IMB NY, USA) software packages (PASW Statistics for Windows, version 19). Frequency tables were analyzed using the Chi-square test, with likelihood ratio (LR) or Fischer's exact test to assess the significance of the correlation between the categorical variables. Odds Ratios (OR) and their $95 \%$ Confidence Intervals (95\% CI) were calculated where appropriate, using the exact method. Univariate survival analysis for the outcome measure (DSS, DFS) was based on Kaplan-Meier method, with log-rank (Mantel-Cox) comparison test. In all tests, the values $p<0.05$ were considered as statistically significant.

\section{Results}

Expression patterns of Her2/neu protein profiling \& amplification status of Her2/neu gene in transitional cell carcinoma of urinary bladder

The staining patterns and prevalence rate of Her2/neu protein profile and amplification status of Her2/neu gene respectively, are illustrated in Fig. 1. The expression of Her2/ neu protein is mainly membranous. The frequencies of expression patterns of Her2/neu protein receptors in 160 of bladder cancer samples evaluated by IHC technique were: no expression (negative, $15 \%$ ), weak expression $(+1,25 \%)$, moderate expression $(+2,36 \%)$ and strong expression patterns $(+3,24 \%)$, respectively (Fig. 2 . A1-3), while the corresponding frequencies of amplification status of Her2/neu gene evaluated by BDISH technique were: non-amplified Her $2 /$ neu gene status $(75 \%)$ and amplified Her2/neu gene status (25\%), respectively (Fig. 2. B1-3).

\section{Concordance rate between IHC and BDISH for evaluating Her2/neu protein/gene status in transitional cell carcinoma of urinary Bladder}

Data showed that the two techniques have a reasonable concordance rate in evaluating the Her2/neu status in bladder cancer (Table 2). The concordance rate was estimated in 156 samples. Interestingly, 27/38 (71 \%) of bladder cancer samples which, showed +3 over-expression patterns of Her2/neu protein have amplification $(>2)$ of their corresponding Her2/neu gene while only $29 \%$ (11/38) of overexpressed Her2/neu proteins showed non-amplified $(<2)$ $\mathrm{Her} 2 /$ neu gene, respectively. Surprisingly, all cases of low expression patterns of Her2/neu protein profile $(0 /+1) 60 /$ $60(100 \%)$ showed non-amplification $(<2)$ of corresponding Her2/neu gene, i.e. also that no sample 0/60 (0 \%) of low expression $(0 /+1)$ samples showed amplification $(>2)$ of corresponding Her2/neu gene. While in cases of borderline/equivocal (+2) expression pattern of Her2/neu protein, attractively, just about 46/58 (79 \%) of samples showed non-amplification $(<2)$ of corresponding Her2/neu gene and 12/58 (21 \%) of samples showed amplified $(>2)$ correspondent Her $2 /$ neu gene, respectively $(p<0.005)$.

\section{Correlation of IHC Her2/neu protein expression and BDISH Her2/neu gene status with clinico-pathological features}

Our data showed that both age and gender had no significant relationship with the expression pattern of Her2/neu protein (Table 3). However, the involvement of lymph nodes was significantly associated with more Her2/neu protein expression pattern $(p<0.04)$. Regarding the stage of the tumor, there was a highly significant correlation between expression patterns of Her2/neu protein and stage of the disease. In fact, high stage tumors expressed more Her2/neu protein receptors compared to those of low stage $(p<0.002)$. Interestingly, the same trend was also observed with vascular invasion status where tumors with vascular invasion showed more expressed Her2/neu protein pattern profile as compared to tumors with no vascular invasion $(p<0.01)$. However, a correlation of borderline significance was observed between tumors with distant metastasis as contrasted to those with no metastasis $(p<0.07)$. Moreover, the study 

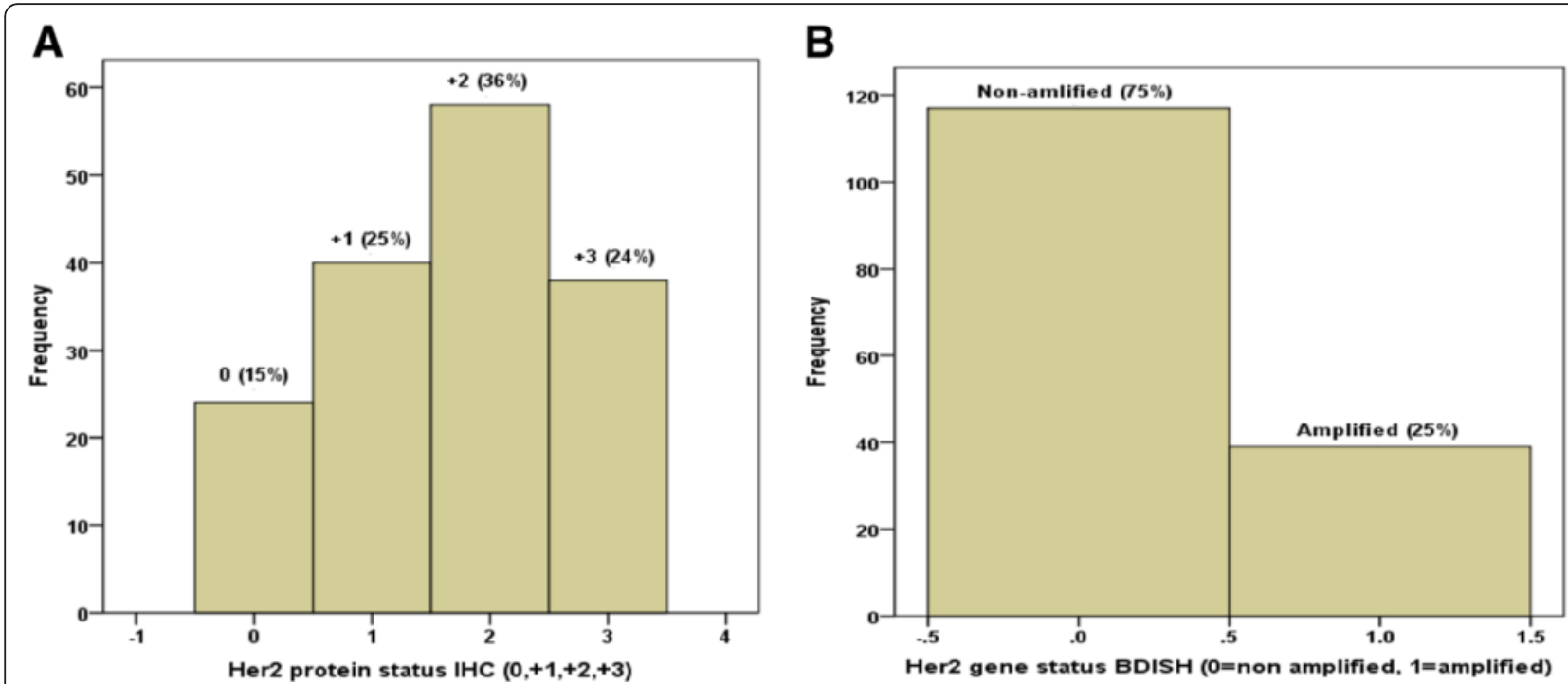

Fig. 1 Histograms showed the frequency of expression patterns of Her2/neu protein receptors in 160 of bladder cancer by IHC (a) with corresponding amplification status of her2/neu gene of the same samples by using BDISH technique (b)

demonstrated that higher tumor grade was associated with amplified Her2/neu gene status as compared to low grade tumors $(p<0.03$, data not shown).

\section{Correlation of IHC Her2/neu protein expression and BDISH Her2/neu gene status with survival outcome}

The survival data were available for 155 patients. KaplanMeier survival analysis showed that there was a significant $(p<0.02, \log$ rank) difference in DSS between patients with non-amplified Her2/neu gene status tumors who living significantly longer (longer DSS) as compared with those with amplified Her2/neu gene status tumors (Fig. 3). In other words, the study showed that at 60 months ( 5 years) follow up time, about $80 \%$ of patients with amplified Her2/nue gene were died of disease as compared to only $42 \%$ of their counterparts with non-amplified Her $2 /$ neu. By using the IHC score, the survival analysis showed a trend/tendency of high recurrence rate of cancer patients with high Her2 protein expression pattern as compared to patients who have cancer with low Her2 protein expression pattern. However this correlation was not statistically significant $(p<0.1, \log$ rank, data not shown).

\section{Discussion}

Bladder cancer is the ninth most common and a leading cause of cancer death worldwide [1]. High recurrence rate and heterogeneous features of urothelial bladder cancers are the major hurdles that hamper a suitable clinical management [21]. The latter depends enormously on several clinico-pathological factors such as tumor grade, stage and lymph node invasion [22]. Hence there is an urgent need to develop new diagnostic and therapeutic modalities to meet clinical needs for the management of bladder cancer. Recent advances in cancer research have improved our understanding of the biological features of the disease and unveil relevant biomarkers that are currently used in cancer stratification, screening, diagnosis and prognosis [23]. In the last decade, human epidermal growth factor receptor 2 (Her2/ neu) has emerged as a potential biomarker in many cancer types especially breast, colorectal and gastric cancers [14, 24-26]. Over-expression of Her2/neu protein and gene amplification is associated with increased tumor growth and poor prognosis and targeted Her2/neu therapy has proven to be promising in breast cancer treatment [13]. However, the clinical relevance of Her2/ neu in bladder cancer remains ambiguous and underinvestigated. This fact has strongly urged us to analyze the expression patterns of Her2/neu status using two independent experimental techniques to assess its prognostic and/or predictive value in our cohort of bladder cancer patients, therefore better clinical management scenarios will be foreseen for them.

In the present study, we used a cohort of 160 consent patients with TCC of bladder cancer along with their full set of clinico-pathological data. IHC results showed that that Her2/neu protein was expressed in $60 \%$ of the analyzed samples. The percentage of the Her2/neu protein over-expressed (3+) was observed in $24 \%$ of patients. Previous published reports revealed that over-expression of Her2/neu protein is highly variable in bladder cancer ranging from 9.2 to $71 \%$ [27-29]. This variability could be attributed to several factors such as sample size, detection method used, scoring criteria and ethnic origin [16]. However, the most important finding in the current study was that expression of Her2/neu correlated 


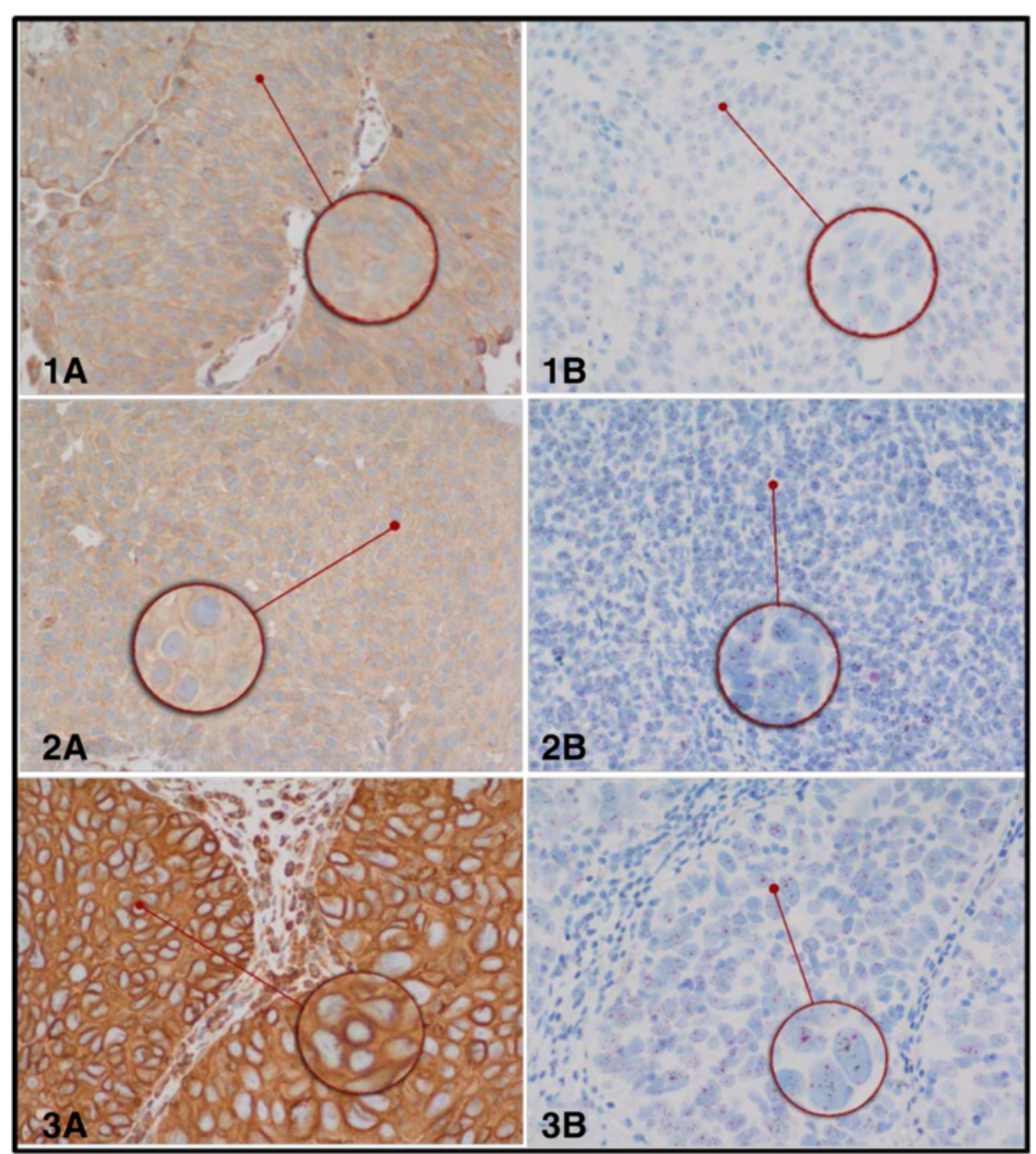

Fig. 2 Validation and concordance rate of both $\mathrm{HC}$ (A1-3) and corresponding BDISH (B1-3) of TMA spots for Her2/neu protein expression and Her2/neu gene amplification patterns, respectively. Figures (1a-1b) represented 1+ membranous expression patterns (negative) of Her2/neu protein (1a) and Non-amplified Her2/neu gene status (1b). Figures (2a-2b) represented 2+ membranous expression patterns (borderline) of Her2/ neu protein (2a) and amplified Her2/neu gene status (2b). While, figures (3a-3b) represented 3+ membranous expression patterns (high) of Her2/ neu protein (3a) and corresponding amplified Her2/neu gene status (3b) in TCC of urinary bladder. Magnification is X40

significantly with tumor stage, vascular invasion, lymph node invasion and distant metastasis. Our observation is consistent with previous findings where Her2/neu status correlated significantly with lymph node metastases from urothelial bladder cancer compared to the primary tumors [30,31]. This observation indicates that Her2/ neu is a valuable biomarker and/or effector associated to the metastatic potential of tumor cells and provide merit to exploring targeted Her2/neu therapy in patients with metastatic bladder cancer [16, 32].

Table 2 Concordance rate between IHC and BDISH techniques for evaluating Her2/neu protein/gene status in transitional cell carcinoma of urinary bladder $(p<0.005)$

\begin{tabular}{|c|c|c|c|c|}
\hline & & \multicolumn{3}{|c|}{ Her2/neu gene status (BDISH) } \\
\hline & & Non-Amplified $(\leq 2)$ & Amplified (>2) & Total \\
\hline \multirow[t]{4}{*}{ Her2/neu protein expression patterns (IHC) } & Weak Expression $(0,1+)$ & $60(100 \%)$ & $0(0 \%)$ & 60 \\
\hline & Borderline/equivocal Expression (2+) & $46(79 \%)$ & $12(21 \%)$ & 58 \\
\hline & High Expression (3+) & $11(29 \%)$ & 27 (71 \%) & 38 \\
\hline & Total & 117 & 39 & 156 \\
\hline
\end{tabular}


Table 3 Correlation between Her2/neu protein expression patterns and clinico-pathological features of transitional cell carcinoma of urinary bladder

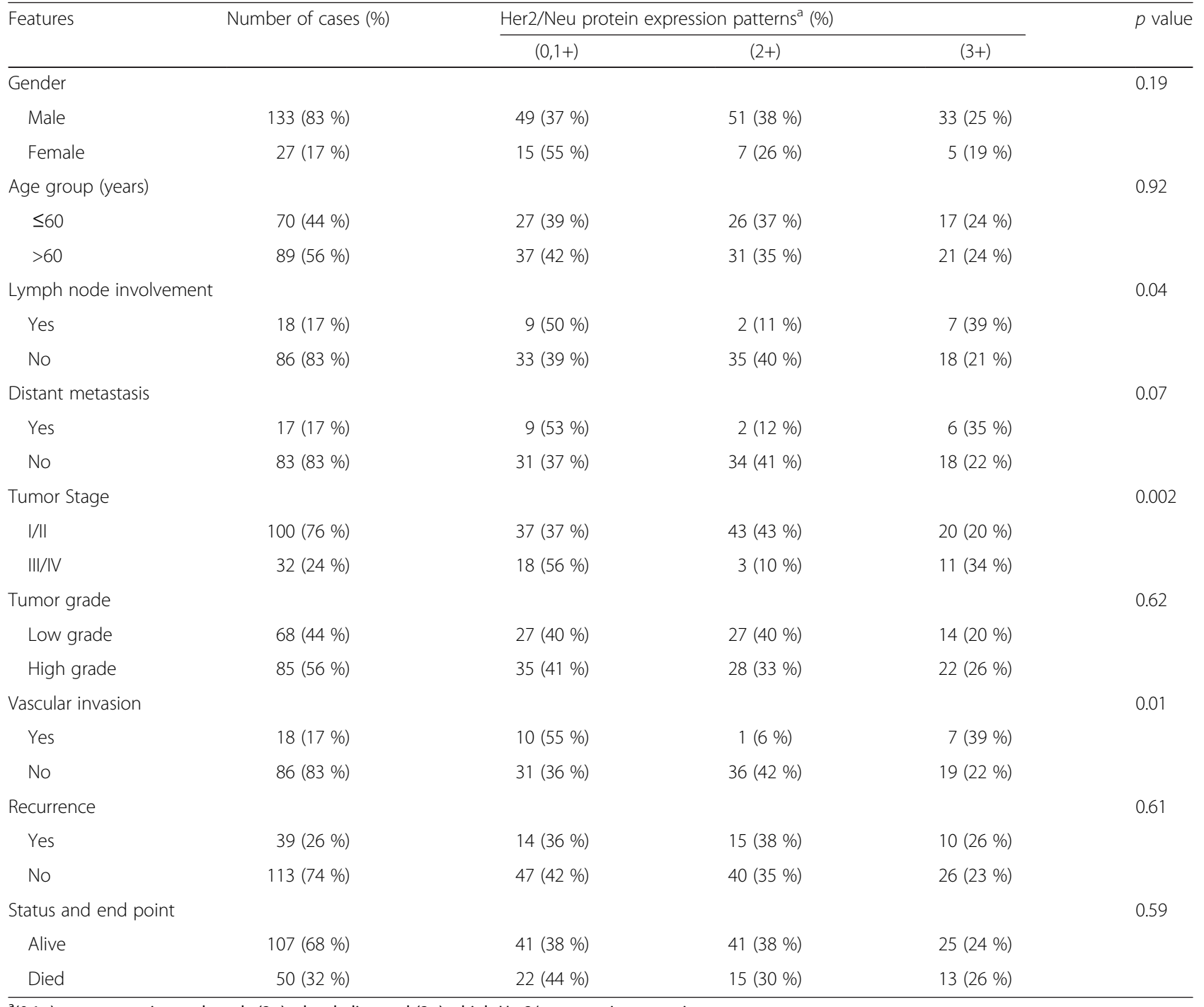

${ }^{a}(0,1+)=$ no expression and weak, $(2+)=$ borderline and $(3+)=$ high Her2/neu protein expression patterns

Interestingly, high correlation between $\mathrm{Her} 2 /$ neu gene amplification and tumor grade was observed $(p=0.03)$. Increased amplification of Her2/neu was more common in higher histological grades than lower ones in several cancers including breast, bladder and osteosarcoma [33-35]. Similar correlations between Her2/neu status with highgrade and advanced stages (III/IV) were also reported in bladder cancer supporting more aggressive and proliferative diseases with these patients [36].

In an independent approach, we carried out BDISH to investigate the status of Her2/neu gene in order to validate our IHC $2+$ group and assess the concordance between the two techniques. Despite some discrepancies regarding the level of concordance between IHC and FISH methods [37-39], so often both techniques consolidate each other and generate similar results $[27,40,41]$. Despite that IHC is more cost-effective and recommended by some studies [42], it has been reported that assessing Her2/neu gene amplification using in situ hybridization technique is a more reliable and accurate method to evaluate $\mathrm{Her} 2 / \mathrm{neu}$ status in breast cancer patients $[36,43]$. Here we report that Her2/neu is amplified in $25 \%$ of the analyzed cohort which is in line with IHC data. Although a reasonable concordance rate for Her $2 /$ neu testing by $\mathrm{IHC}$ and BDISH was achieved in our cohort, higher concordance between these two platforms were also previously reported in urothelial carcinoma [44]. This rate is below the threshold mandated by the new ASCO-CAP guidelines [45]. However, the use of the emerging digital droplet $\mathrm{PCR}$ as a new promising 


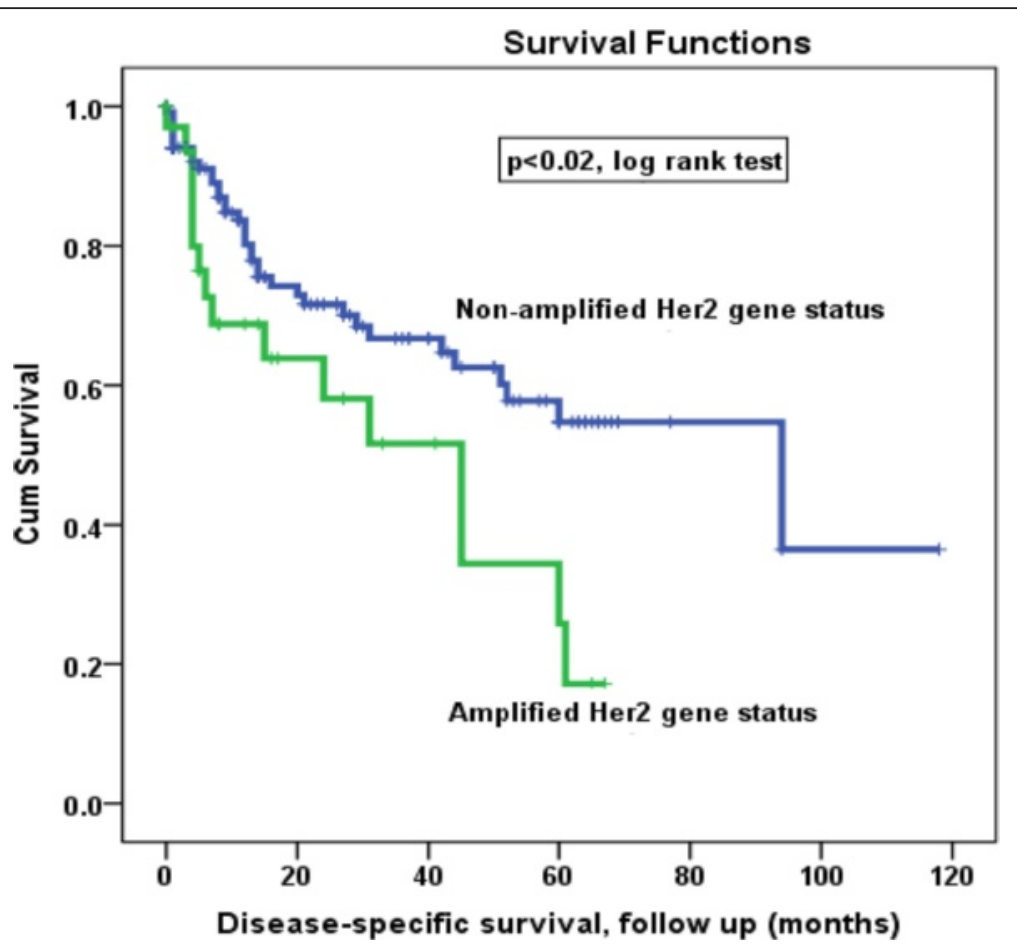

Fig. 3 Kaplan Meier analysis of Her2/neu gene status in bladder cancer. Disease-specific Survival (DSS) outcome for patients according to their Her2/neu gene amplification status $(p<0.02$, log-rank test)

technology which may help improving the accuracy of Her2/neu copy number variation and reinforce these two FDA-approved approaches for better clinical outcomes [46].

Kaplan Meier survival curve revealed that amplification of Her2/neu gene is significantly associated with a poor prognosis and shorter overall survival (Fig. 3). However, patients with non-amplified Her2/neu gene were associated with prolonged DSS suggesting Her2/ $n e u$ as an independent prognosticator of overall survival in bladder cancer $(p=0.02)$. This association was previously examined in many cancer types [12, 36, 47, 48]. The enhancement of cancer cell proliferation, motility, invasion and metastasis are possible factors that support such poor prognostic impact of Her2/neu on the overall survival in bladder cancer patients [49-51]. Additionally, previous findings reported an interesting impact of anti-Her2 targeted therapy (Trastuzumab) in the treatment of bladder cancer with amplified/ overexpressed HER2. In fact, $70 \%$ of bladder cancer patients with amplified HER2 were shown to respond completely or partially but safely to Trastuzumab treatment [52, 53]. Additional studies using larger patients' cohorts and randomized trials are required to validate these urothelial bladder cancer survival outcomes results and to investigate further the antiHER2 targeted therapy in Her2/neu overexpression patients in clinical trial setting.

\section{Conclusion}

Our results showed a reasonable concordance rate between IHC and BDISH supporting that both approaches can be used to assess the Her2/neu status. The discrepancies between both approaches are expected since they are affected by the experimental context and the preanalytical conditions. The use of digital droplet PCR could be a good alternative for validation of these two FDA-approved approaches given its high accuracy, sensitivity and cost-effectiveness.

We reported herein and for the first time in Saudi Arabia that $24 \%$ of our patients' cohort have Her2/neu over-expression. Although this Her2/neu (over-expression/ amplification) status reported herein requires further validation using larger cohorts of patients, it was significantly associated with disease aggressiveness and poor outcome. Our results together with previous findings provide new insight into the role of Her2/neu in TCC patients who might benefit from anti-Her2/neu targeted therapy in clinical trial setting especially those with locally advanced and metastatic Her2/neu amplified bladder cancer.

\section{Acknowledgments}

The authors would like to acknowledge with thanks Science and Technology Unit, King Abdulaziz University for technical support.

\section{Funding}

This project was funded by the National Plan for Science, Technology and Innovation (MAARIFAH) - King Abdulaziz City for Science and Technology - the Kingdom of Saudi Arabia - award numbers (10-BIO-1260-03) \& (26-33- ). 


\section{Availability of data and materials}

Data will not be shared because of a confidentiality agreement with a clinical partner in order to initiate a clinical trial study.

\section{Authors' contributions}

TN participated in retrieving and revising the clinico-pathological follow up data and drafted the manuscript. JA participated in revising the pathological diagnosis and helped in constructing the TMA slides. MA participated in analysis of data, helped in designing images, tables and drafted the manuscript. AD carried out the statistical analysis of study. HA carried out the experiment. AC participated in constructing the design of study. AAS participated in providing the clinical samples. AAA participated in providing the clinical samples. AA participated in designing the study and provided the antibodies for the experiment. $A B$ participated in the design of the study, carried out the experiment, statistical analysis and helped in drafting the manuscript. MAQ helped in providing the reagents, kits and other logistics in order to perform the study. All authors read and approved the final manuscript.

\section{Competing interests}

The authors declare that they have no competing interests.

\section{Consent for publication}

Not applicable.

\section{Ethics approval and consent to participate}

In order to perform the study, written informed consents were taken from all participants in this study and both clinical and follow up data were retrieved according to the permission and guidelines of the Ethical Committee of King Abdulaziz University Hospital (KAUH) under the reference number \#149-14.

\section{Author details}

${ }^{1}$ King Fahd Medical Research Center, King Abdulaziz University, PO BOX 80216, Jeddah 21589, Saudi Arabia. ²Department of Pathology, Faculty of Medicine, King Abdulaziz University Hospital, Jeddah, Saudi Arabia. ${ }^{3}$ Center of Excellence in Genomic Medicine Research, Faculty of Applied Medical Sciences, King Abdulaziz University, PO BOX 80216, Jeddah 21589, Saudi Arabia. ${ }^{4}$ Department of Urology, Faculty of Medicine, King Abdulaziz University Hospital, Jeddah, Saudi Arabia. ${ }^{5}$ Department of Urology, King Faisal Specialist Hospital \& Research Centre, Jeddah, Saudi Arabia.

\section{Received: 7 April 2016 Accepted: 10 August 2016}

\section{Published online: 19 August 2016}

\section{References}

1. Jemal A, Bray F, Center MM, Ferlay J, Ward E, Forman D. Global cancer statistics. CA Cancer J Clin. 2011;61(2):69-90.

2. Siegel RL, Miller KD, Jemal A. Cancer statistics, 2015. CA Cancer J Clin. 2015;65(1):5-29.

3. Sylvester RJ, van der Meijden APM, Oosterlinck W, Witjes JA, Bouffioux C, Denis L, Newling DWW, Kurth K. Predicting recurrence and progression in individual patients with stage Ta T1 bladder cancer using EORTC risk tables: a combined analysis of 2596 patients from seven EORTC trials. Eur Urol. 2006;49(3):466-77.

4. Prout Jr GR, Barton BA, Griffin PP, Friedell GH. Treated history of noninvasive grade 1 transitional cell carcinoma. The National Bladder Cancer Group. J Urol. 1992;148(5):1413-9.

5. Youssef RF, Lotan Y. Predictors of outcome of non-muscle-invasive and muscle-invasive bladder cancer. Sci World J. 2011:11:369-81.

6. Knowles MA, Hurst CD. Molecular biology of bladder cancer: new insights into pathogenesis and clinical diversity. Nat Rev Cancer. 2015;15(1):25-41.

7. Cheung G, Sahai A, Billia M, Dasgupta P, Khan MS. Recent advances in the diagnosis and treatment of bladder cancer. BMC Med. 2013;11(1):13.

8. Ménard S, Casalini P, Campiglio M, Pupa SM, Tagliabue E. Role of HER2/neu in tumor progression and therapy. Cell Mol Life Sci. 2004;61(23):2965-78.

9. Gutierrez C, Schiff R. HER2: biology, detection, and clinical implications. Arch Pathol Lab Med. 2011;135(1):55-62.

10. Gravalos C, Jimeno A. HER2 in gastric cancer: a new prognostic factor and a novel therapeutic target. Ann Oncol. 2008;19(9):1523-9.

11. Al-Khattabi H, Kelany A, Buhmeida A, Al-Maghrabi J, Lari S, Chaudhary A, Gari M, Abuzenadah A, Al-Qahtani M. Evaluation of HER-2/neu gene amplification by fluorescence in situ hybridization and immunohistochemistry in Saudi female breast cancer. Anticancer Res. 2010;30(10):4081-8.

12. Slamon D, Clark G, Wong S, Levin W, Ullrich A, McGuire W. Human breast cancer: correlation of relapse and survival with amplification of the HER-2/ neu oncogene. Science. 1987;235(4785):177-82.

13. Slamon D, Eiermann W, Robert N, Pienkowski T, Martin M, Press M, Mackey J, Glaspy J, Chan A, Pawlicki M, et al. Adjuvant trastuzumab in HER2-positive breast cancer. N Engl J Med. 2011;365(14):1273-83.

14. Bang Y-J, Van Cutsem E, Feyereislova A, Chung HC, Shen L, Sawaki A, Lordick F, Ohtsu A, Omuro Y, Satoh T, et al. Trastuzumab in combination with chemotherapy versus chemotherapy alone for treatment of HER2positive advanced gastric or gastro-oesophageal junction cancer (ToGA): a phase 3, open-label, randomised controlled trial. Lancet. 2010;376(9742):687-97

15. Yan M, Schwaederle M, Arguello D, Millis SZ, Gatalica Z, Kurzrock R. HER2 expression status in diverse cancers: review of results from 37,992 patients. Cancer Metastasis Rev. 2015:34(1):157-64.

16. Bellmunt J, Werner L, Bamias A, Fay AP, Park RS, Riester M, Selvarajah S, Barletta JA, Berman DM, de Muga S, et al. HER2 as a target in invasive urothelial carcinoma. Cancer Med. 2015;4(6):844-52.

17. Zhau HE, Zhang X, Von Eschenbach AC, Scorsone K, Babain RJ, Ro JY, Hung M-C. Amplification and expression of the c-erb B-2/neu proto-oncogene in human bladder cancer. Mol Carcinog. 1990;3(5):254-7.

18. Park JC, Hahn NM. Bladder cancer: a disease ripe for major advances. Clin Adv Hematol Oncol. 2014;12:838-45.

19. Al-Maghrabi J, Emam E, Gomaa W, Saggaf M, Buhmeida A, Al-Qahtani M, Al-Ahwal M. c-MET immunostaining in colorectal carcinoma is associated with local disease recurrence. BMC Cancer. 2015;15:676.

20. Wolff AC, Hammond MEH, Schwartz JN, Hagerty KL, Allred DC, Cote RJ, Dowsett M, Fitzgibbons PL, Hanna WM, Langer A. American Society of Clinical Oncology/College of American Pathologists guideline recommendations for human epidermal growth factor receptor 2 testing in breast cancer. Arch Pathol Lab Med. 2007;131(1):18-43.

21. Lawrence MS, Stojanov P, Polak P, Kryukov GV, Cibulskis K, Sivachenko A Carter SL, Stewart C, Mermel CH, Roberts SA, et al. Mutational heterogeneity in cancer and the search for new cancer-associated genes. Nature. 2013;499(7457):214-8

22. Cianfrocca M, Goldstein LJ. Prognostic and predictive factors in early-stage breast cancer. Oncologist. 2004;9(6):606-16.

23. Kelloff GJ, Sigman CC, Scher HI. Biomarker development in the context of urologic cancers. Urol Oncol. 2015;33(6):295-301.

24. Witton CJ, Reeves JR, Going JJ, Cooke TG, Bartlett JMS. Expression of the HER1-4 family of receptor tyrosine kinases in breast cancer. J Pathol. 2003;200(3):290-7.

25. Ingold Heppner B, Behrens HM, Balschun K, Haag J, Krüger S, Becker T, Röcken C. HER2/neu testing in primary colorectal carcinoma. Br J Cancer. 2014:111(10):1977-84.

26. Ahmed S, Sami A, Xiang J. HER2-directed therapy: current treatment options for HER2-positive breast cancer. Breast Cancer. 2015:22(2):101-16.

27. Lae M, Couturier J, Oudard S, Radvanyi F, Beuzeboc P, Vieillefond A Assessing HER2 gene amplification as a potential target for therapy in invasive urothelial bladder cancer with a standardized methodology: results in 1005 patients. Ann Oncol. 2009;21(4):815-9.

28. Jimenez RE, Hussain M, Bianco FJ, Vaishampayan U, Tabazcka P, Sakr WA, Pontes JE, Wood DP, Grignon DJ. Her-2/neu overexpression in muscleinvasive urothelial carcinoma of the bladder prognostic significance and comparative analysis in primary and metastatic tumors. Clin Cancer Res. 2001;7(8):2440-7.

29. Gandour-Edwards R, Lara PN, Folkins AK, LaSalle JM, Beckett L, Li Y, Meyers FJ, DeVere-White R. DoesHER2/neu expression provide prognostic information in patients with advanced urothelial carcinoma? Cancer. 2002;95(5):1009-15.

30. Matsubara H, Yamada Y, Naruse K, Nakamura K, Aoki S, Taki T, Tobiume M, Zennami K, Katsuda R, Honda N. Potential for HER-2/neu molecular targeted therapy for invasive bladder carcinoma: Comparative study of immunohistochemistry and fluorescent in situ hybridization. Oncol Rep. 2008

31. Fleischmann A, Rotzer D, Seiler R, Studer UE, Thalmann GN. Her2 amplification is significantly more frequent in lymph node metastases from urothelial bladder cancer than in the primary tumours. Eur Urol. 2011;60(2):350-7. 
32. Carneiro BA, Meeks JJ, Kuzel TM, Scaranti M, Abdulkadir SA, Giles FJ. Emerging therapeutic targets in bladder cancer. Cancer Treat Rev. 2015:41(2):170-8.

33. Lal P, Tan LK, Chen B. Correlation of HER-2 status with estrogen and progesterone receptors and histologic features in 3,655 invasive breast carcinomas. Am J Clin Pathol. 2005;123(4):541-6.

34. Ma Q, Zhou Y, Ma B, Chen X, Wen Y, Liu Y, Fan Q, Qiu X. The clinical value of CXCR4, HER2 and CD44 in human osteosarcoma: A pilot study. Oncol Lett. 2012;3(4):797-801.

35. Afzal M, Amir M, Hassan MJ, Hussain MS, Aziz MN, Murad S, Murtaza I, Anees M, Sultan A. Clinical role of HER2 gene amplification and chromosome 17: a study on $154 \mathrm{IHC}$-equivocal cases of invasive breast carcinoma patients. Tumour Biol. 2016 [Epub ahead of print].

36. Hammam O, Nour HH, Mosaad M, Akl M, Khalil H, Al Ganzory H, Hindawi A. The clinical significance of HER2 protein amplification/expression in urinary bladder lesion. Arab J Urol. 2015;13(2):146-52.

37. Li MH, Hou CL, Wang C, Sun AJ. HER-2, ER, PR status concordance in primary breast cancer and corresponding metastatic lesion in lymph node in Chinese women. Pathol Res Pract. 2016;212(4):252-7.

38. Lim TH, Lim AS, Thike AA, Tien SL, Tan PH. Implications of the updated 2013 American Society of Clinical Oncology/College of American pathologists guideline recommendations on human epidermal growth factor receptor 2 gene testing using immunohistochemistry and fluorescence in situ hybridization for breast cancer. Arch Pathol Lab Med. 2016;140(2):140-7.

39. Kruger S, Weitsch G, Buttner H, Matthiensen A, Bohmer T, Marquardt T, Sayk F, Feller A, Bohle A. Overexpression of c-erbB-2 oncoprotein in muscle-invasive bladder carcinoma: relationship with gene amplification, clinicopathological parameters and prognostic outcome. Int J Oncol. 2002;21:981-7.

40. Chen PC-H, Yu H-J, Chang Y-H, Pan C-C. Her2 amplification distinguishes a subset of non-muscle-invasive bladder cancers with a high risk of progression. J Clin Pathol. 2013;66(2):113-9.

41. Gown AM, Goldstein LC, Barry TS, Kussick SJ, Kandalaft PL, Kim PM, Tse CC. High concordance between immunohistochemistry and fluorescence in situ hybridization testing for HER2 status in breast cancer requires a normalized IHC scoring system. Mod Pathol. 2008;21(10):1271-7.

42. Pyo JS, Sohn JH, Kim WH. Concordance rate between HER2 immunohistochemistry and in situ hybridization in gastric carcinoma: systematic review and meta-analysis. Int J Biol Markers. 2016;31(1):e1-10.

43. Dybdal N, Leiberman G, Anderson S, McCune B, Bajamonde A, Cohen RL, Mass RD, Sanders C, Press MF. Determination of HER2 gene amplification by fluorescence in situ hybridization and concordance with the clinical trials immunohistochemical assay in women with metastatic breast cancer evaluated for treatment with trastuzumab. Breast Cancer Res Treat. 2005;93(1):3-11.

44. de Pinieux G, Colin D, Vincent-Salomon A, Couturier J, Amsellem-Ouazana $D$, Beuzeboc P, Vieillefond A. Confrontation of immunohistochemistry and fluorescent in situ hybridization for the assessment of HER-2/ neu (c- erb b-2) status in urothelial carcinoma. Virchows Arch. 2004;444(5):415-9.

45. Wolff AC, Hammond ME, Hicks DG, Dowsett M, McShane LM, Allison KH, Allred DC, Bartlett JM, Bilous M, Fitzgibbons P, et al. Recommendations for human epidermal growth factor receptor 2 testing in breast cancer: American Society of Clinical Oncology/College of American Pathologists clinical practice guideline update. J Clin Oncol. 2013;31(31):3997-4013.

46. Belgrader P, Tanner SC, Regan JF, Koehler R, Hindson BJ, Brown AS. Droplet digital PCR measurement of HER2 copy number alteration in formalin-fixed paraffin-embedded breast carcinoma tissue. Clin Chem. 2013;59(6):991-4.

47. Ang YL, Yong WP, Tan P. Translating gastric cancer genomics into targeted therapies. Crit Rev Oncol Hematol. 2016;100:141-6.

48. Zhao J, Xu W, Zhang Z, Song R, Zeng S, Sun Y, Xu C. Prognostic role of HER2 expression in bladder cancer: a systematic review and meta-analysis. Int Urol Nephrol. 2014;47(1):87-94.

49. Brouxhon SM, Kyrkanides S, Teng X, O'Banion MK, Clarke R, Byers S, Ma L. Soluble-E-cadherin activates HER and IAP family members in HER2+ and TNBC human breast cancers. Mol Carcinog. 2013;53(11):893-906.

50. Asrani K, Keri RA, Galisteo R, Brown SAN, Morgan SJ, Ghosh A, Tran NL, Winkles JA. The HER2- and Heregulin 1 (HRG)-Inducible TNFR Superfamily Member Fn14 Promotes HRG-Driven Breast Cancer Cell Migration, Invasion, and MMP9 Expression. Mol Cancer Res. 2013;11(4):393-404.

51. Skagias L, Politi E, Karameris A, Sambaziotis D, Archondakis A, Vasou O, Ntinis A, Michalopoulou F, Moreas I, Koutselini $\mathrm{H}$, et al. Prognostic impact of
HER2/neu protein in urothelial bladder cancer. Survival analysis of 80 cases and an overview of almost 20 years' research. J BUON. 2009;14(3):457-62.

52. Hussain MH, MacVicar GR, Petrylak DP, Dunn RL, Vaishampayan U, Lara Jr PN, Chatta GS, Nanus DM, Glode LM, Trump DL, et al. Trastuzumab, paclitaxel, carboplatin, and gemcitabine in advanced human epidermal growth factor receptor-2/neu-positive urothelial carcinoma: results of a multicenter phase II National Cancer Institute trial. J Clin Oncol. 2007;25(16):2218-24.

53. Peyromaure M, Scotte F, Amsellem-Ouazana D, Vieillefond A, Oudard S, Beuzeboc P. Trastuzumab (Herceptin) in metastatic transitional cell carcinoma of the urinary tract: report on six patients. Eur Urol. 2005;48(5):771-5.

\section{Submit your next manuscript to BioMed Central and we will help you at every step:}

- We accept pre-submission inquiries

- Our selector tool helps you to find the most relevant journal

- We provide round the clock customer support

- Convenient online submission

- Thorough peer review

- Inclusion in PubMed and all major indexing services

- Maximum visibility for your research

Submit your manuscript at www.biomedcentral.com/submit
C Biomed Central 